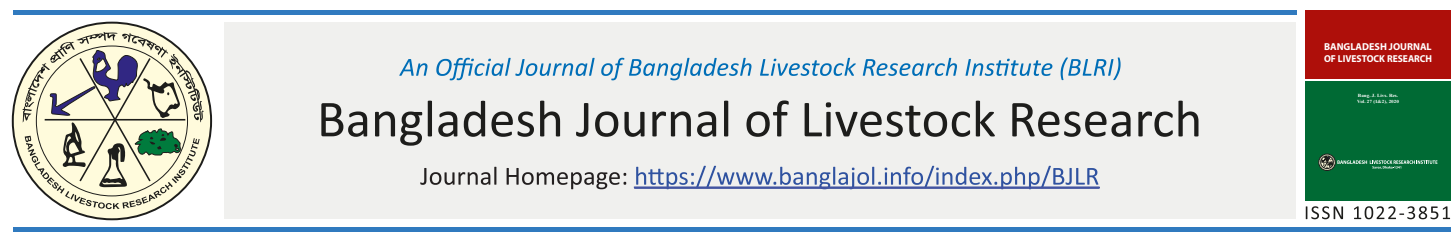

\title{
Effect of supplementing feed grade L-methionine in plant sourced diet on the performance of broiler chicken
}

\author{
T. Mahmud 1 , M. A. Hossain ${ }^{1 *}$, M. J. Uddin'1 , I. Jahan², M. H. Ahmad ${ }^{3}$ and M. M. Hossain \\ ${ }^{1}$ Department of Dairy \& Poultry Science, Chattogram Veterinary and Animal Sciences \\ University, Khulshi, Chattogram-4225, Bangladesh \\ ${ }^{2}$ Department of Botany, University of Chittagong, Chittagong-4331, Bangladesh \\ ${ }^{3}$ Remount Veterinary \& Farm Corps, Bangladesh Army, Jashore, Bangladesh \\ ${ }^{4}$ Quality Control Lab, Savar, Dhaka, Bangladesh
}

\begin{abstract}
The study was conducted to investigate the productivity and profitability of broiler on L-methionine supplemented diet. A total of 160 day-old broiler chicks (Cobb 500) was randomly distributed to four dietary supplements, $\mathrm{D}_{0}$ (Control), $\mathrm{D}_{1}(0.30 \% \mathrm{~L}-\mathrm{Met}), \mathrm{D}_{2}(0.35$ $\%$ L- Met $)$ and $\mathrm{D}_{3}(0.40 \% \mathrm{~L}-\mathrm{Met})$. Each treatment was replicated five times with 8 birds per cage. The chicks were reared in the battery cages while they were fed with broiler starter diet (crumble) until Day14 of age. The birds with fed with L-Met supplemented diets starting from Day15 until Day35 of age All the diets were iso-caloric and iso-nitrogenous.. Results revealed that the L-Met supplementations were in favor of higher live weight $(\mathrm{LW})$ and better $(\mathrm{p}<0.05)$ feed conversion ratio without affecting the feed intake (FI). The $\mathrm{D}_{3}$ diet resulted higher $(\mathrm{p}<0.01) \mathrm{LW}$ in the birds than all others on Day35 of age. The livability $(\%)$ was unaffected $(p>0.05)$ by the dietary supplements. No significant $(p>0.05)$ difference was observed in the relative weights of visceral organs (small intestine, proventriculus, gizzard, liver and heart) except for the spleen. Relatively increased $(\mathrm{p}<0.05)$ spleen weight $(\%)$ was observed in the $\mathrm{D}_{3}$ diet. The breast weight $(\%)$ was increased marginally $(\mathrm{p}<0.07)$ in the $\mathrm{D}_{3}$ group, while the other carcass parts; breast weight, thigh weight, wing weight, shank weight, drumstick weight, neck weight, and abdominal fat content were found to be similar $(\mathrm{p}>0.05)$ in the dietary groups. Higher profit $(\mathrm{p}<0.01)$ and lower production cost $(\mathrm{p}<0.05)$ were observed in the $\mathrm{D}_{3}$ group than that of the others. It can be inferred that $0.40 \%$ L-Met supplementation in the broiler diet is better for growth performance and profitability.
\end{abstract}

Key words: Growth, carcass characteristics, viability, L-Met, profitability, broiler chicken Bang. J. Livs. Res. Vol. 27 (1\&2), 2020: P. 1-14. $\quad$ https://doi.org/10.3329/bjlr.v27i1.55165

\section{Introduction}

Methionine is considered to be Sulphurcontaining amino acids (AA), which is important for the supplementation in the poultry for their optimum growth and development It is clear that poultry can not synthesize methionine or essential AA adequately to meet the requirement, so broiler diet is always

*Corresponding author: mahossain@cvasu.ac.bd 
supplemented with synthetic AA (methionine, lysine). Both essential and non-essential AA are inevitable for the proper growth and development of broiler chicken. Poultry can synthesize only non-essential AA in proper ratio and amount as required by their body. For this reason, non- essential AA need not to be supplied to the broiler chickens through diets (Singh and Panda, 1992). For optimum growth and carcass yield development of the fast-growing meat chickens, require adequate supply of essential AA in their diet. For feather growth, meat, muscle, tissue or cell development of bird need optimum level of protein supply in the ration. It is needless to say that essential AA (methionine) plays an important role in energy production, protein synthesis, growth performance, feed efficiency, feed utilization and immunity of broiler (Bunchasak, 2009; Elnesr et al., 2019)

The muscle growth or body development of broiler chickens is nothing but the improvement of their body conformation of muscle attachment. It is blatant that plant protein lacks in indispensable AA with lower biological value. Further reported that essential AA are not found in the vegetable proteins in proper ratio and amount as required for the optimum growth and development of the broilers (Hossain et al., 2013). Broiler chicken could demonstrate poorer growth performance when they are reared with all-vegetable diet (Hossain et al., 2013) only. So, researchers, scientists and feed formulators will need to be alert or cautious to formulate broiler diet using plant sourced ingredients. For this reason, it is very much needed to supply synthetic indispensable AA always in broiler diet to ensure their optimum growth and development.

Commercial broiler chicken is nearly impossible to rear without the supplemental essential AA (lysine, methionine) in their diet (Akter, 2018). So ration formulation for poultry always requires indispensable AA supplement. In this regard, the deficiency of synthetic AA, particularly methionine in the market can lead to a great crisis for ration formulation for commercial poultry farming.

Methionine (Met) is always incorporated from synthetic source to compensate the protein or essential AA requirement in poultry diet formulation. Methionine is available in the market in two forms, i.e DL-methionine and L-methionine. DL-methionine (DL Met), is more common in the market than that of L-methionine (L-Met). However, recent introduction of L-methionine in the market has drawn a great attention to the poultry integrators. It is reported that L-Met is more active than that of DL-Met, and it is only biologically functional form of methionine, which is readily utilized and absorbed by the intestinal cells of young animals (Akter, 2018). On the contrary, DL-Met is not utilized directly by the cells of the gastrointestinal tract until it is converted to L-Met in either the liver or the kidneys. Further, recent studies reported that the growth performance of broiler chicken is improved when the broiler chicken fed with 
L-Met conventional diet compared to that of DL-Met (Hossain, 2018, Akter, 2018, Akter and Hossain, 2019, Akter et al., 2020a,b).

In conventional poultry diets, DL Met is more popularly used as a synthetic source of Met than L-Met. In recent years, feed grade L-Met is available from fermentation process. Thereby, it will provide a natural form of LMet in lieu of synthetic DL-Met in poultry diet supplementation. Feed grade L-Met is assumed to be a new emerging protein feed ingredients in commercial poultry feed industry. Various researches emphasized on L-Met in commercial broiler diet which could play a dominant role to boost up the development of poultry industry of the country. This is why, the current study was carried out so that the findings of the study would be a milestone to determine the recommended dietary level of L-Met for commercial broiler feed formulation. Considering the above, the present study was conducted to assess the productivity and profitability of broiler chicken fed L-Met supplemented diet.

\section{Materials and Methods}

\section{Experimental birds, housing and management} A total of 160 day-old broiler chicks (Cobb 500)was procured from local hatchery to conduct a $35 \mathrm{~d}$ feeding trial in battery cages. The chicks were weighed on receipt, equalized and then randomly assigned into four dietary treatment groups i.e. $\mathrm{D}_{0}, \mathrm{D}_{1}, \mathrm{D}_{2}$ and $\mathrm{D}_{3}$, where each treatment was replicated 5 times with 8 birds per replicate in a completely randomized design (CRD).
Chicks were allotted into 16 pens of equal size that were furnished with a feeder and a drinker. All the birds had a free access to the diet, along with adlibitum fresh, clean drinking water during the entire trial period. The birds were exposed to a continuous lighting program. All the birds were vaccinated against Ranikhet (New Castle Disease) and Gumboro diseases.

\section{Diet formulation}

Four different test diets $\left(\mathrm{D}_{0}, \mathrm{D}_{1}, \mathrm{D}_{2}\right.$ and $\left.\mathrm{D}_{3}\right)$ were formulated with the locally available plant sourced ingredients to meet or exceed the requirements of National Research Council (NRC, 1994). Control diet ( $\left.D_{0}\right)$ was formulated with all the feedstuffs except for L-Met, whereas $\mathrm{D}_{1}, \mathrm{D}_{2}$ and $\mathrm{D}_{3}$ test diets were prepared with the supplementation of L-Met at the rate of $0.30 \%, 0.35 \%$ and $0.40 \%$, w/w of the diet, respectively. The composition and nutritive values (calculated and analyzed in the laboratory) of the formulated or test diets were shown in the Table 2. All the test diets were iso-energetic and iso-nitrogenous, and were supplemented with multi-enzymes (Natuzyme®, Bioproton Pty Ltd., Sunnybank, Australia) according to the level stated by the manufacturing company. Chicks were fed starter diet in crumble form up to 2 weeks of age as an adjustment period (Table 1), after that formulated diets were used in mash form up to $35 \mathrm{~d}$ of age,

\section{Data and sample collection}

Mortality of the bird was recorded as it occurred, while body weight and feed intake were recorded weekly for the calculation of body weight gain, and feed conversion ratio (FCR). Livability was calculated from mortality 
Table 1: Nutrient composition of the ready-made starter diet

\begin{tabular}{ccc}
\hline Nutrient components (\%) & $\begin{array}{c}\text { Composition of the ready- } \\
\text { made feed (analyzed) }\end{array}$ & $\begin{array}{c}\text { Composition of the Company } \\
\text { (reported) }\end{array}$ \\
\hline ME (kcal/kg) & - & 3000 \\
Moisture & 10.40 & 12 \\
DM & 89.60 & 88 \\
CP & 21.80 & 20 \\
CF & 3.30 & 5.0 \\
EE & 5.70 & - \\
Ash & 6.20 & 6.0 \\
Ca & 1.00 & 0.95 \\
Total P & 0.58 & 0.45 \\
Lys & - & 1.05 \\
Met & - & 0.45 \\
\hline
\end{tabular}

@, The ready-made feed was purchased from Nourish Poultry and Hatchery Limited, Dhaka, Bangladesh.

of birds per replicate cage. Two birds per pen were selected randomly, weighed and killed humanely on day 35 to record the relative weight of gastro-intestinal organs (liver, pancreas, heart, small intestine, proventriculus, gizzard, spleen) for assessing the gastro-intestinal development of the bird. Meat yield traits were also collected to appraise the proportionate of different meat cuts of the body (dressing \%, breast weight, thigh, drumstick, shank, neck, wing and abdominal fat). Feed samples were also collected prior and post to supplying to the birds to assess the nutritive value of the feeds. Lastly, all the prices of input supplies say feed cost, chick cost, labour, medication, vaccination and other cost etc., were also recorded to assess the profitability of raising broiler chicken.

\section{Sample processing and analyses}

\section{Feed sample}

After collection the feed samples were processed by grinding with the help of mortar and pestle and then mixed thoroughly for lab analyses. About 500gm of each diet of the finisher as well as starter diet were taken and sent to the laboratory for the proximate analysis of dry matter (DM \%), moisture \%, crude protein (CP \%), crude fiber (CF \%), ether extract (EE\%) and ash using standard laboratory procedure (AOAC, 2007). Dry matter was determined by oven dry method. Crude protein was recovered by Kjeldahl process. Ether Extract was quantified by Soxhlet apparatus. Ash was measured by igniting the pre-ashing sample on a Muffle furnace at a temperature of $600^{\circ} \mathrm{C}$ for four to six hours. Additionally, calcium (Ca \%) and phosphorus (P \%) were determined by atomic absorption and spectrophotometry, respectively (AOAC, 2007). 
Table 2: Ingredient and nutrient composition of the finisher diet

\begin{tabular}{|c|c|c|c|c|}
\hline \multirow[t]{2}{*}{ Feed ingredient (\%) } & \multicolumn{4}{|c|}{ Finisher diet } \\
\hline & Do & $\mathrm{D}_{1}$ & $\mathrm{D}_{2}$ & $\mathrm{D}_{3}$ \\
\hline Corn & 51.00 & 51.00 & 51.00 & 51.00 \\
\hline Wheat & 7.00 & 7.00 & 7.00 & 7.00 \\
\hline Soybean meal & 32.00 & 32.00 & 32.00 & 32.00 \\
\hline Til oil cake & 0.50 & 0.50 & 0.50 & 0.50 \\
\hline Palm oil & 6.70 & 6.60 & 6.59 & 6.55 \\
\hline DCP & 0.70 & 0.70 & 0.70 & 0.70 \\
\hline Limestone & 1.10 & 1.10 & 1.1 & 1.1 \\
\hline Table salt & 0.25 & 0.25 & 0.25 & 0.25 \\
\hline Choline chloride & 0.04 & 0.04 & 0.04 & 0.04 \\
\hline Vitamin $\min$ premix $^{1}$ & 0.25 & 0.25 & 0.25 & 0.25 \\
\hline L-lysine & 0.18 & 0.18 & 0.18 & 0.18 \\
\hline DL-methionine & 0.21 & 0.00 & 0.00 & 0.00 \\
\hline L-methionine & 0.00 & 0.30 & 0.35 & 0.40 \\
\hline Enzymes & 0.04 & 0.04 & 0.04 & 0.04 \\
\hline Toxin Binder & 0.04 & 0.04 & 0.04 & 0.04 \\
\hline \multicolumn{5}{|c|}{ Calculated nutrient component (\%) } \\
\hline ME (kcal/kg) & 3200 & 3200 & 3200 & 3200 \\
\hline $\mathrm{CP}$ & 20.00 & 20.00 & 20.00 & 20.00 \\
\hline $\mathrm{Ca}$ & 0.81 & 0.88 & 0.81 & 085 \\
\hline $\mathrm{P}$ & 0.66 & 0.68 & 0.65 & 0.66 \\
\hline $\mathrm{CF}$ & 3.40 & 3.11 & 3.13 & 3.11 \\
\hline $\mathrm{EE}$ & 3.33 & 3.32 & 3.32 & 3.28 \\
\hline Lysine & 1.10 & 1.20 & 1.12 & 1.12 \\
\hline DL-methionine & 0.49 & 0.49 & 0.49 & 0.49 \\
\hline Threonine & 0.85 & 0.85 & 0.86 & 0.85 \\
\hline \multicolumn{5}{|c|}{ Analyzed nutrient contents (\%) } \\
\hline DM & 88.00 & 88.50 & 88.00 & 87.30 \\
\hline $\mathrm{CP}$ & 19.33 & 19.45 & 19.56 & 19.45 \\
\hline $\mathrm{CF}$ & 5.20 & 5.35 & 5.30 & 5.50 \\
\hline $\mathrm{EE}$ & 9.10 & 9.23 & 9.40 & 9.10 \\
\hline Ash & 5.60 & 5.70 & 5.60 & 5.40 \\
\hline $\mathrm{Ca}$ & 2.25 & 2.35 & 2.18 & 2.72 \\
\hline $\mathrm{P}$ & 0.48 & 0.59 & 0.57 & 0.67 \\
\hline
\end{tabular}

Control diet (Do) supplemented with DL-methionine and no L-methionine, whereas $\mathrm{D}_{1}, \mathrm{D}_{2}$ and $\mathrm{D}_{3}$ diets were supplemented with $0.30,0.35$ and $0.40 \%$ L-methionine, respectively. ${ }^{1}$ Provided per $\mathrm{kg}$ of diet (mg): vitamin A (as all-trans retinol), $3.6 \mathrm{mg}$; cholecalciferol, $0.09 \mathrm{mg}$; vitamin E (as d-a-tocopherol), $44.7 \mathrm{mg}$; vitamin $\mathrm{K} 3,2 \mathrm{mg}$; thiamine, $2 \mathrm{mg}$; riboflavin, $6 \mathrm{mg}$; pyridoxine hydrochloride, $5 \mathrm{mg}$; vitamin B12, $0.2 \mathrm{mg}$; biotin, $0.1 \mathrm{mg}$; niacin, $50 \mathrm{mg}$; D-calcium pantothenate, $12 \mathrm{mg}$; folic acid, $2 \mathrm{mg}$; Mn, 80mg; Fe, $60 \mathrm{mg}$; Cu, $8 \mathrm{mg}$; I, $1 \mathrm{mg}$; Co, $0.3 \mathrm{mg}$ and Mo, $1 \mathrm{mg}$. 


\section{Statistical analyses}

All collected data were subjected to analyze by one way ANOVA using Minitab software (Minitab Version 16, 2000). The significance of differences between means was tested using the Duncan's multiple range test (DMRT). Statistical significance was considered at $\mathrm{p} \leq 0.05$.

\section{Results}

\section{Feed intake and live weight}

The results of the feed intake (FI) and live weight (LW) of broiler chickens were shown in Table 3. It is obvious from the data that the birds on $\mathrm{D}_{3}$ diet group consumed the highest amount of feed compared to other groups, even though there respectively, except for the days of 1-35d (Table 3). The LW of broiler was influenced significantly $(\mathrm{p}<0.01)$ among treatments from 1-35 days. The birds fed on D3 group attained the highest LW compared to others dietary group.

\section{The feed conversion ratio (FCR)}

The FCR of the broiler was significantly $(\mathrm{p}<0.05)$ influenced by dietary treatment from day 14-35 (Figure 1). Birds on D1and D3 diet group had a comparatively better FCR value $(1.78 ; 1.80)$ than that of other diet group. However, FCR value between treatment was statistically different $(\mathrm{p}<0.05)$ throughout the trial period.

\section{Livability}

The response of broiler in terms of livability

Table 3: Feed intake (FI) and live weight (LW) of broilers fed L-methionine diets

\begin{tabular}{cccccccc}
\hline & Age (day) & \multicolumn{5}{c}{ Treatment } & \multicolumn{3}{c}{ SEM } & P-values \\
\cline { 3 - 6 } & & $\mathrm{D}_{0}$ & $\mathrm{D}_{1}$ & $\mathrm{D}_{2}$ & $\mathrm{D}_{3}$ & & \\
$\mathrm{FI}(\mathrm{g} / \mathrm{b})$ & $14-21$ & 707.07 & 726.07 & 749.29 & 805.89 & 14.737 & 0.152 \\
& $21-28$ & 989.00 & 999.40 & 966.10 & 997.20 & 12.775 & 0.786 \\
& $14-35$ & 2688.00 & 2732.00 & 2717.60 & 2811.10 & 26.425 & 0.430 \\
& $1-14$ & 576.14 & 560.0 & 561.75 & 577.82 & 6.44 & 0.669 \\
$\mathrm{LW}(\mathrm{g} / \mathrm{b})$ & $1-21$ & 1025.30 & 1035.50 & 1030.60 & 1065.60 & 11.30 & 0.606 \\
& $1-35$ & $1895.40^{\mathrm{d}}$ & $2014.30^{\mathrm{c}}$ & $2096.90^{\mathrm{b}}$ & $2144.30^{\mathrm{a}}$ & 22.375 & 0.01 \\
\hline
\end{tabular}

Data indicate mean values of seven birds per replicate from 1-35 days; $\mathrm{D}_{\mathrm{o}}$ refers to control diet with no supplemental L-methionine, whereas $\mathrm{D}_{1}, \mathrm{D}_{2}$ and $\mathrm{D}_{3}$ diets are supplemented with $0.30,0.35$ and $0.40 \%$ L-methionine, respectively; SEM- pooled standard errors mean

was no significant $(\mathrm{p}>0.05)$ difference between treatment. The live weight (LW) of broiler chicken had no significant ( $p>0.05)$ difference between treatment groups from 1-14 days and 1-21 days, up to 35 days of age was not found significantly different $(\mathrm{P}>0.05)$ between treatments (Figure 2). The result revealed that supplemental diet had no detrimental effect on the viability or survivability of broiler chicks. 


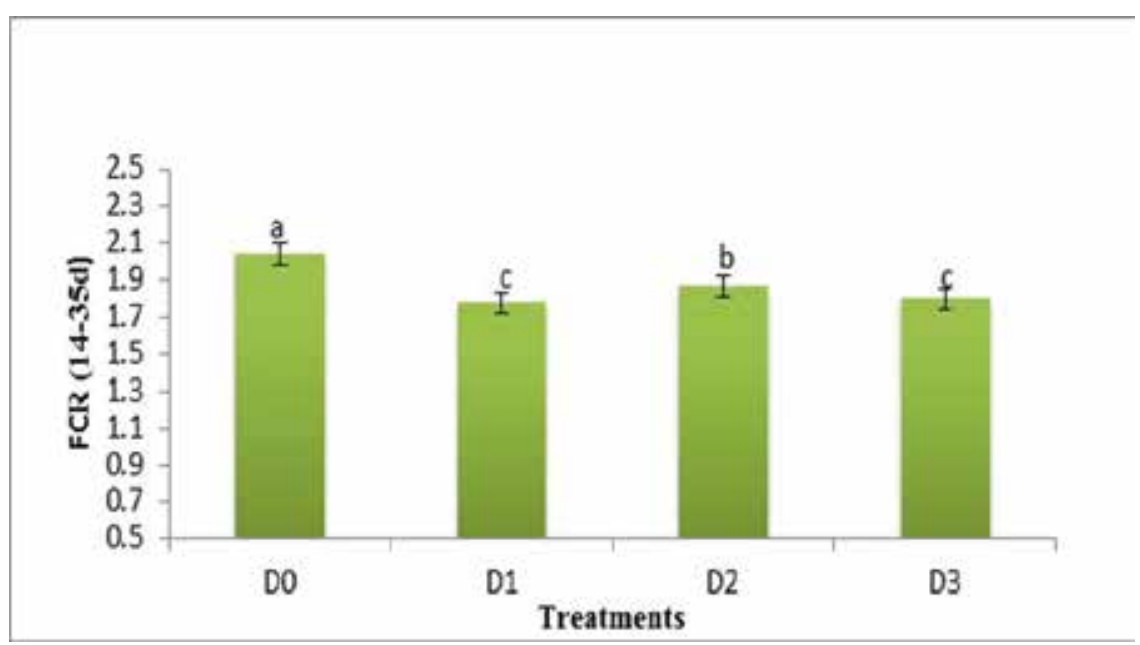

Figure 1: Feed conversion ratio (FCR) of broilers fed L-Met diets on day 35; Bar diagram with different letters means significant difference $(\mathrm{p}<0.05)$ among treatments

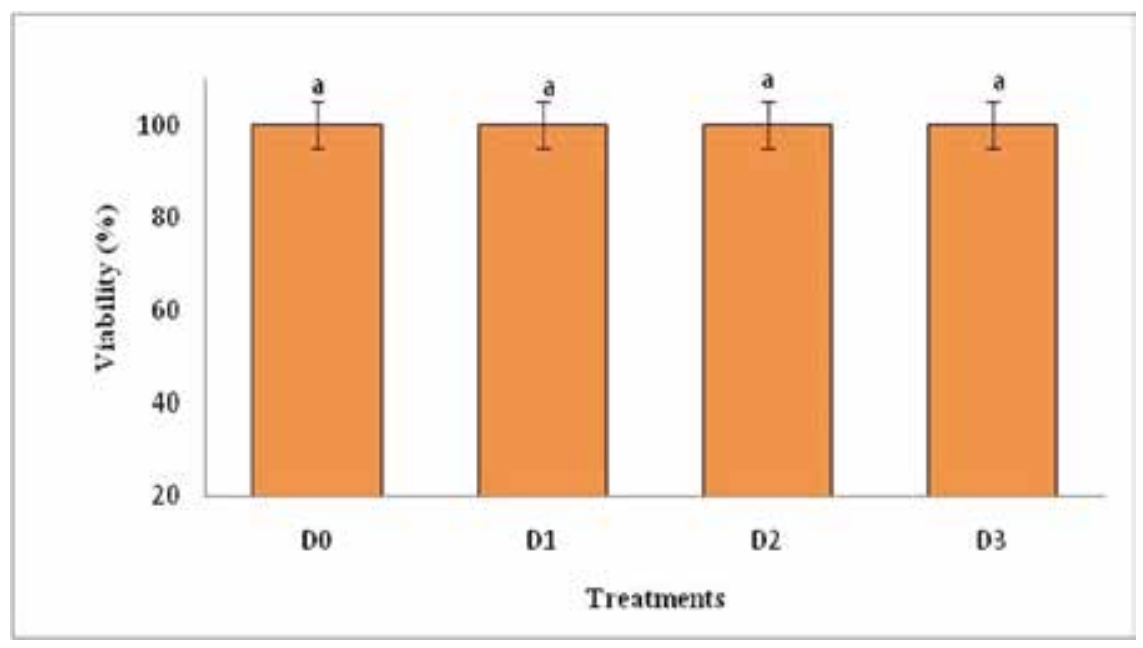

Figure 2: Livability of broilers fed L-meth diets on day 35; Bar with similar letter has no significant difference $(\mathrm{P}>0.05)$ among treatments

\section{Meat yield parameters of broiler chickens}

Results of meat yield traits demonstrated that all the meat cuts were found to be identical ( $p>0.05$ ) among treatments (Table 4). The findings indicated that breast weight is influenced $(\mathrm{p}<0.07)$ marginally by the dietary treatment, where the highest breast (\%) was attained in the $\mathrm{D}_{3}$ diet group.

\section{Gastro-intestinal organ development}

The result of different visceral organs like small intestine, proventiculus, gizzard, liver, heart, spleen and pancreas of the birds were not influenced $(\mathrm{P}>0.05)$ by dietary treatments (Table 5). Only spleen weight (\%) of broiler chickens is found to be statistically significant $(\mathrm{p}<0.05)$ among four dietary 
treatments. The highest spleen weight was attained in the $\mathrm{D}_{3}$ diet group as compared to that of other diet groups. The pancreas $(\mathrm{p}<0.01)$ less for the birds fed L-Met supplemented diets. Higher $(\mathrm{p}<0.01)$ profit margin was obtained for L-Met supplemented

Table 4: Meat yield traits $(100 \mathrm{~g})$ of broilers fed L-methionine in diet

\begin{tabular}{|c|c|c|c|c|c|c|}
\hline & \multicolumn{4}{|c|}{ Treatment } & \multirow[t]{2}{*}{ SEM } & \multirow[t]{2}{*}{ P-values } \\
\hline & $\mathrm{D}_{0}$ & $\mathrm{D}_{1}$ & $\mathrm{D}_{2}$ & $\mathrm{D}_{3}$ & & \\
\hline Dressing $(\%)$ & 63.0 & 65.23 & 65.75 & 67.78 & 1.512 & 0.211 \\
\hline Breast weight & 25.19 & 30.13 & 29.08 & 33.09 & 1.460 & 0.07 \\
\hline Drumstick weight & 8.27 & 9.39 & 8.54 & 8.93 & 0.414 & 0.794 \\
\hline Thigh weight. & 10.33 & 11.49 & 10.21 & 10.80 & 0.522 & 0.820 \\
\hline Shank weight & 3.91 & 4.38 & 3.91 & 4.17 & 0.253 & 0.892 \\
\hline Neck weight & 2.28 & 2.56 & 2.19 & 2.42 & 0.197 & 0.912 \\
\hline Wing weight & 5.03 & 4.91 & 4.47 & 5.09 & 0.381 & 0.934 \\
\hline Abdominal fat weight & 2.08 & 1.92 & 1.79 & 2.07 & 0.107 & 0.741 \\
\hline
\end{tabular}

Each value indicates the mean of four replicates consist of 7 birds per replicate cage at 35 days; Values bearing different superscript in a row differ significantly; SEM- pooled standard errors of mean

Table 5: Relative weight of visceral organs $(\mathrm{g} / 100 \mathrm{~g})$ of broilers fed L-methionine in diet

\begin{tabular}{|c|c|c|c|c|c|c|}
\hline \multirow[t]{2}{*}{ Parameter } & \multicolumn{4}{|c|}{ Treatment } & \multirow[t]{2}{*}{ SEM } & \multirow[t]{2}{*}{ P-values } \\
\hline & $\mathrm{D}_{0}$ & $\mathrm{D}_{1}$ & $\mathrm{D}_{2}$ & $\mathrm{D}_{3}$ & & \\
\hline${ }^{1}$ Small intestine weight & 2.56 & 2.50 & 2.34 & 2.56 & 0.120 & 0.901 \\
\hline Proventiculus + gizzard & 3.12 & 3.27 & 3.26 & 3.80 & 0.150 & 0.475 \\
\hline Liver weight & 1.61 & 2.17 & 2.14 & 2.22 & 0.116 & 0.340 \\
\hline Heart weight & 0.40 & 0.41 & 0.42 & 0.43 & 0.019 & 0.950 \\
\hline Spleen weight & $0.08^{b}$ & $0.09^{b}$ & $0.15^{\mathrm{a}}$ & $0.16^{\mathrm{a}}$ & 0.003 & 0.05 \\
\hline Pancreas weight & 0.15 & 0.19 & 0.18 & 0.23 & 0.007 & 0.075 \\
\hline
\end{tabular}

Each value indicates the mean of four replicates consisting of 4 birds per replicate cage at 35 days 1Organ (small intestine was weighed with contents

weight (\%) were also tended to be significantly $(\mathrm{p}<0.075)$ different between treatment.

\section{Cost effectiveness and economic analyses}

The data on cost benefit analyses of the broiler is presented in the Table 6 . Significantly higher $(\mathrm{p}<0.05)$ total production cost was found in the birds fed non-supplemented or basal diets (D0). Total cost of production was significantly dietary group. The greater profit margin might be due to increased body weight gain and reduced production cost per treatment group. On the other hand, lower profit $(\mathrm{p}<0.01)(\mathrm{Tk} / \mathrm{Kg}$ live broiler) was counted for the birds fed diets without L-Met diets.

\section{Discussion}

Gross responses of broiler chicken fed L-Met supplemented vegetable sourced-diets Generally, the key performance indicators 
or the most important criteria for ascertaining the performance of broiler chicken include growth rate, feed efficiency and carcass yield traits (Rezaei et al., 2004). It is evident from our current study that body growth of broiler chicken improved significantly when they fed on L-Met supplemented vegetable sourced-diet. It is broiler chicken. In addition, the increased absorption of L-Met diet might increase the protein level and thereby the increased growth of the broiler chickens. Shen et al. (2015) reported that the L-Met is directly absorbed by the intestinal tissue of broilers compared to the DL- Met. L-methionine is absorbed directly into body proteins, but the

Table 6: Cost of production and profit analyses of broilers fed L-Met diets on d 35

\begin{tabular}{lcccccc}
\hline & \multicolumn{9}{c}{ Treatment } & SEM & P-values \\
\cline { 2 - 5 } & $\mathrm{D}_{0}$ & $\mathrm{D}_{1}$ & $\mathrm{D}_{2}$ & $\mathrm{D}_{3}$ & & \\
Live weight (g/bird) & $1895.40^{\mathrm{d}}$ & $2014.30^{\mathrm{c}}$ & $2096.90^{\mathrm{a}}$ & $2144.30^{\mathrm{b}}$ & 22.375 & 0.01 \\
Survivability (\%) & 100.0 & 100.0 & 100.0 & 100.0 & 0.000 & 0.10 \\
Market price (Tk/kg live wt) & 153.00 & 153.00 & 153.00 & 153.00 & - & - \\
Total production cost (Tk/kg live & $146.55^{\mathrm{a}}$ & $138.95^{\mathrm{b}}$ & $130.00^{\mathrm{c}}$ & $131.70^{\mathrm{c}}$ & 0.466 & 0.01 \\
broiler) & & & & & & \\
Profit (Tk/kg live broiler) & $6.45^{\mathrm{d}}$ & $14.05^{\mathrm{c}}$ & $23.05^{\mathrm{a}}$ & $21.30^{\mathrm{b}}$ & 0.125 & 0.01 \\
\hline
\end{tabular}

Values bearing different superscript in a row differ significantly as shown above

noted that live weight of broiler was improved when the broiler chicks were fed on the increased level of the supplemental L-Met diets. The greater body weight of broilers of this diet group might be a result of improved FCR of broiler chickens fed LMet diet, as is observed in this current study. The improved body weight and better FCR of broilers on L-Met diet could be likely due to amino acid (AA) balance (Bunchasak et al., 2009), as it is reported that plant sources feedstuffs contain inadequate sources of essential amino acid.. Besides, the utilization of single AA Met appears to be greater than that of other essential AA from the view point of AA metabolism in the gastro-intestinal tract (Stoll et al., 1998). Further, it could be assumed that supplemental L-Met in all vegetable diet might enrich the adequacy of essential AA in broiler diet, and this balanced AA might enhance the body growth performance of
D-methionine must first be converted into keto-methionine and then into the L-methionine before being incorporated into body protein (Drazbo et al., 2015).

It supported the hypothesis that L-Met is better utilized by young broiler chicks compared with D-Met. The difference in the functionalities and roles for intestinal development of young broiler chicks are speculated as the reasons for the difference in growth performance. However, our present findings agree with the report of previous investigators (Shen et al., 2014, 2015, Akter, 2018, Hossain, 2018, Akter and Hossain, 2019, Akter et al., 2020b). This findings largely supported by Marrett and Sunde, (1965) and Bhargava et al. (1970), who stated that chicks fed with L-Met grew better than that of D-Met.

The result of feed intake of broiler chickens up to 35 days was not influenced by dietary 
treatments in this study. The birds of $\mathrm{D}_{3}$ diet group consumed the greater amount feed than the other dietary group, even though no significant difference was observed anomg treatments. Our results contradict with the report of previous researchers (Akter, 2018, Akter and Hossain, 2019, Akter et al., 2020b), who found increased feed intake when broiler fed conventional diets supplemented with different level of L-Met. The discrepancy of feed intake between two different trials might occur due to different type of feedstuffs are supplied the birds. This similar result was also found by other researcher, who stated that adding supplemental Met to diet increased feed consumption of birds (Bunchasak and Keawarun, 2006).

\section{Livability and L-Met diet}

The livability (\%) of broiler remains unaffected between treatments according to the findings of current study. It might be speculated that L-Met diet had no significant effect on the viability of broiler chickens in terms of growth and development of broiler. This is why, L-Met supplemented in broiler diets can be used undoubtedly because of no detrimental effect for the growth and viability of the broiler chicken. Our result agrees with the report of previous researcher (Akter., 2018, Akter et al., 2020a), who found similar responses on viability of broilers, when broiler fed conventional diets with different level of L-Met.

\section{Meat yield parameter of broiler chicken}

The marginally increased breast meat deposition of broiler fed on L-Met vegetable diet than those of DL-met diet, might be due to better absorption of sulphur containing AA.
Dietary methionine levels have been shown to increase breast meat yield reported by previous investigators (Hickling et al., 1990; Huyghebaert et al., 1994). In another study, Drazbo et al. (2015) observed that higher dietary methionine levels improve breast muscle yield of broiler chickens, but they have no influence on meat quality, except for improvement in tenderness. Studies have indicated that an increase in dietary protein content could result in increased carcass protein content and decreased carcass fat content (Bedford and Summers, 1985).

\section{Development of gastro-intestinal tract}

The results of gastro-intestin organs development denotes that spleen weight of broiler chickens was found to be significantly improved. The highest spleen weight was found in the $\mathrm{D}_{3}$ diet group rather than other diet groups. In addition, the relative weight of pancreas was also somewhat increased in the broiler fed similar diet $\left(\mathrm{D}_{3}\right)$. The greater weights of the organs might occur as a resultant of the improved body weight of broiler chickens, as is observed in this study. It could be assumed that the increased pancreas weight of broiler chicken fed L-Met diet might influence more release of digestive enzymes, which could enhance the nutrient digestibility of feed along with better growth responses of the birds. Besides, the higher metabolic function rate or absorption of L-Met than of DL-Met might also influence the better growth responses of these organs. The growth and development of the gastrointestinal tract requires a variety of functions of AA metabolism, including protein synthesis, cell signaling, anti-oxidative function, and immune function (Shoveller et al., 2003). 
The metabolism and functionalities of AA could represent a functional requirement by the gastrointestinal tract. Therefore, the functional role of Met in the gastrointestinal tract, especially its anti-oxidative effect, could be the main effects on the health of the gastrointestinal tract of a rapid growing animal, and consequently impact its growth (Shen et al., 2014). The hypothesis implies that L-Met as a direct source of Met had greater beneficial effects on gastrointestinal tract development compared with D-Met. Consequently, D-Met has less anti-oxidative function in mucosa cell compared with L-Met (Kuzmicky et al., 1977; Friedman and Gumbmann, 1988).

\section{The profitability of broilers fed L-Met supplemented vegetable sourced-diet}

Vegetable feeds are cheaper in cost than animal sources feed. Diet made from all vegetable sources feedstuffs could be cost effective and profitable in rearing broiler chickens. Any way, it is clear from the cost benefit data that broilers fed diet supplementation with L-Met attained greater body weight with lower cost in this study. The higher profit margin might be occurred due to gaining higher body weight and lower production cost. Net cost was also varied among the experimental groups. However, the variation of return or profit margin occurred mainly due to variation in feed intake, feed cost (per kg) and mortality in different experimental groups. The results agree with the previous researcher (Akter et al., 2020a), who reported that net profit was significantly highest in the broilers fed L-Met supplemented diet compared to DL-Met fed the broiler chicken. In addition, our findings might be partly coincided with the previous report of Zhai et al. (2016), who showed that the increasing amount of supplementary recommended level of Met from 80 to 100,120 , or $140 \%$ lowered the ratio of feed cost: value of cut-up parts.

However, the criteria by which the cost and benefit and performance of birds are evaluated (live weight, carcass yield, or cut-up part value, total production cost of per $\mathrm{kg}$ live weight) as well as the current feed costs and market meat prices, might affect feed cost or production cost in relation to its economic returns (Corzo et al., 2010., Zhai et al., 2013). Because feed ingredient prices, meat prices and other costs required for the broiler production constantly change, it is necessary to continually re-evaluate the relationship between feed ingredient costs and subsequent chick cost, processing yield in order to maximize the profit margin.

\section{Conclusion}

The study revealed that, body weight, FCR, breast weight and spleen weight were improved by supplemented diet fed to the broilers. Further, higher gross net profit was also obtained by the broilers fed supplemented diet. Viability, feed intake and most of the meat yield traits were not influenced by the supplemented diet. It is speculated from the result that growth performance and cost benefit analyses of the Cobb 500 might bring a great benefit from broiler chicken fed feed grade L-Met supplemented diet at their finishing period. Further research on supplemented diets would be a milestone to improve such diets to develop profitable poultry business. It could be concluded that chicks fed diets supplemented with L- Met might respond better growth than those of chicks fed diets with DL- Met. 


\section{Acknowledgement}

The authors are greatly acknowledged to the internal grant of CVASU funded by UGC, Bangladesh for conducting the experiment.

\section{References}

Association of Official Analytical Chemists (AOAC). 2007. Official Methods of Analysis. 18th ed. Association of Official Analytical Chemists; Arlington VA, USA. Dijfdffngfgm fd

Akter, N. , Islam, M. S., Zaman, S., Jahan, I. , Hossain, M. A. 2020a:.The impact of different levels of L-methionine (L-Met) on carcass yield traits, serum

metabolites, tibial characters, and proofitability of broilers fed conventional diet. J. Adv. Vet. Anim. Res. 7: 253-259.

Akter, N., Islam, M. S., Hossain, M. A., Jahan, I., Ahmad, M. H. and Hossain, M. M. 2020b. Ascertaining the Growth Performance, Ileal Gut Morphology, Gastro-intestinal Development and viability of Broiler Chicken fed L-Methionine (L-Met) supplemented diet. Int. J. Poult. Sci.. 19: 477-485.

Akter, N. and Hossain, M. A. 2019. The growth responses, meat yield traits, bone quality, gastro-intestinal development and blood serum profile of broilers fed diet supplemented with feed grade L-methionine. Proceedings of the 11th International Poultry Seminar, WPSA-BB, Dhaka, Bangladesh, PP: 282-284.
Akter, N. 2018. The efficacy of feed grade L-methionine on the productivity of broiler chickens fed conventional diet. MS Thesis, Dept. of Dairy and Poultry Science, CVASU, Chittagong.

Bedford, M.R, and Summers, J.D.. 1985. Influence of the ratio of essential to non-essential amino acids on performance and carcass composition of the broiler chick. Br. Poult. Sci.. 26: 483-491.

Bhargava, K.K, Hanson, R.P,. Sunde, M.L. 1970. Effects of methionine and valine on antibody production in chicks infected with Newcastle disease virus. J. Nutr.. 100: 241-248.

Bhargava K.K, Hanson, R.P, Sunde, M.L. 1971. Effects of Methionine and valine on Growth and Antibody Production in Chicks Infected with Live or Killed Newcastle Disease Virus. J. Poult. Sci. 50:614-19.

Brosnan, J.T, Brosnan, M.E. 2006. The sulfur-containing amino acids: an overview. J. Nut. 136:1636-1640.

Bunchasak, C., and Keawarun, N. 2006. Effect of methionine hydroxy analogue-free acid on growth performance and chemical composition of liver of broiler chicks fed a corn-soybean diet from 0 to 6 weeks of age J. Anim. Sci., 77. 95-102

Bunchasak , C. 2009. Role of dietary methionine in poultry production. J. Poult. Sci.. 46: 169-179.

Corzo, A, Schilling, M.W, Loar, R.E, Mejia, L, Barbosa, L.C.G.S and Kidd, M.T. 
2010. Responses of Cobb x Cobb 500 broilers to dietary amino acid density regimens. J. Appl. Poult. Res'. 19: 227-236

Drazbo, A., Kozlowski, K, ChwastowskaSiwiecka I, Sobczak, A., Kwiatkowski, P, Lemme, A. 2015. Effect of different dietary levels of DL-methionine and the calcium salt of DL-2-hydroxy-4-[methyl] butanoic acid on the growth performance, carcass yield and meat quality of broiler chickens. Euro. Poult. Sci, 79:1-14

Elnesr, S.S., Elwan, H.A.M., Xu, Q.Q., Xie ,C., Dong, X.Y., Zou, X.T. 2019. Effects of in ovo injection of sulfur-containing amino acids on heat shock protein 70 , corticosterone

hormone, antioxidant indices, and lipid profile of newly hatched broiler chicks exposed to heat stress during incubation. Poult. Sci. 98:2290-2298.

Friedman, M., and Gumbmann,, M.R. 1988. Nutritional value and safety of methionine derivatives, isomeric dipeptides and hydroxyl analogs in mice. J. Nutr.. 118: 388-397.

Hickling, D., Guenter. W., Jackson. M.E.. 1990. The effects of dietary methionine and lysine on broiler chicken performance and breast meat yield. Canadian J. Anim. Sci.. 70: 673-678.

Huyghebarert, G, Pack, M, D.E. Grooote, G. 1994. Influence of protein concentration on the response of broilers to upplemental DL-methionine. Archiv für
Geflügelkunde. 58: 23-29

Hossain, M. A. 2018. The efficacy of feed grade L-methionine on the productivity of broiler chickens fed conventional diet. Annual Research Review Workshop, CVASU, Chittagong, Bangladesh, P.33.

Hossain, M. A, Islam, A. F, and Iji, P.A.. 2013. Growth responses, excreta quality, nutrient digestibility, bone development and meat yield traits of broiler chickens fed on vegetable or animal protein diets. S. Afr. J. Anim. Sci ; 43: 208 -18.

Kuzmicky, D,D, Kohler ,G.O, Walker, H.G, Mackey, B.E.. 1977. Availability of oxidized sulfur amino acids for the growing chick. Poult. Sci.. 56: 1560-1565.

Marrett, LE, and Sunde, M.L. 1965. The Effect of other d amino acids on the utilization of the isomers ofmethionine and its hydroxy analogue. Poult. Sci. 44: 957-964.

National Research Council. 1994. Nutrient Requirements of Poultry. 9th revised edition National Academic Press, Washington, DC.

Rezaei, M., Moghaddam, H.,N., Reza, J.,P., Kermanshahi, H. (2004). The effect of dietary protein and lysine levels on broiler performance and carcass characteristics and $\mathrm{N}$ excretion. Int. J. Poult. Sci.. 3:148-152.

Shen, Y.B, Ferket, P.R, Park, I, Malheiros, R.D., Kim, S.W.. 2015. Effects of feed grade -methionine on intestinal redox status, intestinal development, and growth performance of young 
chickens compared with conventional -methionine. J. Anim. Sci.. 93(6): 2977-2986.

Shen, Y.B, Weaver A.C, Kim, S.W.. 2014. Effect of feed grade L-methionine on growth performance and gut health in nursery pigs compared with conventional DL-methionine. . Anim. Sci., 92: 55305539.

Shoveller A.K, Brunton J.A, House J.D, Pencharz, P.B, Ball. R.O. 2003. Dietary cysteine reduces the methionine requirement by an equal proportion in both parenterally and enterally fed piglet s.J. Nutr. 133 (12): 4215-4224.

Singh, K.S, and Panda, B. 1992. Poultry Nutrition. Kalyani Publishers, New Delhi, India, pp. 57-61.

Stoll, B., Henry, J, Reeds, P.J, Yu. H, Jahoor, F., Burrin, D.G.. 1998.
Catabolism dominates the first pass intestinal metabolism of dietary essential amino acids in milk protein-fed piglets. J. Nutr. 128606-14.

Zhai, W., Peebles, E.D., Schilling, M.W, Mercier, Y.. 2016. Effects of dietary lysine and methionine supplementation on Ross 708 male broilers from 21 to $42 \mathrm{~d}$ of age (I): growth performance, meat yield, and cost effectiveness. Bri. Poult. Sci., 25: $197-211$

Zhai, W., Peebles. E.D, Zumwalt. C.D, Mejia, L, Corzo, A. 2013. Effects of dietary amino acid density regimens on growth performance and meat yield of Cobb $\times$ Cobb 700 broilers. J Appl. Poult. Res., 22:447-60. 